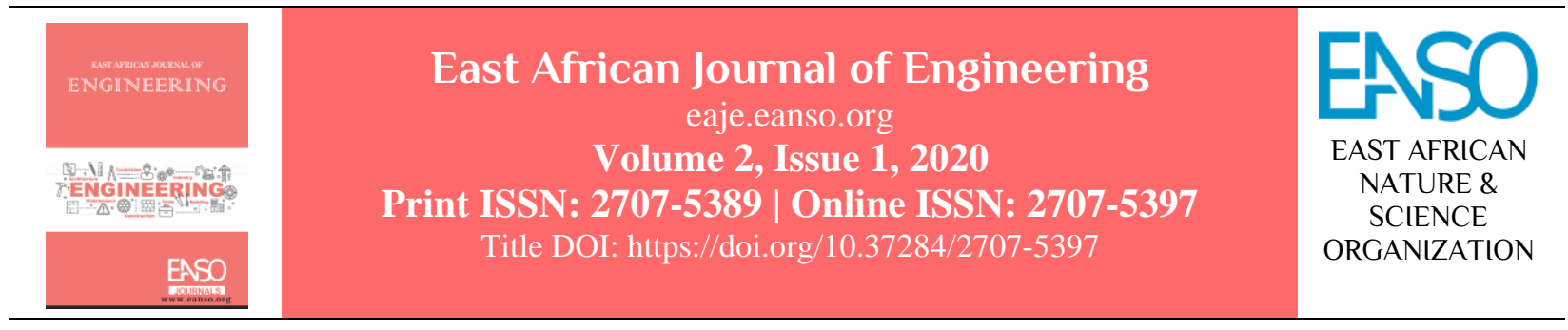

Original Article

\title{
Application of Natural Radionuclide in the Subsurface Hydrogeology of Selected Two Local Governments in South Western Nigeria
}

\author{
Jeje Julius Olatunji ${ }^{1 *}$, Muritala Oluwaseun Arowolo ${ }^{1} \&$ Adeniyi Ayokunle Sodipo ${ }^{1}$ \\ ${ }^{1}$ Department of Civil Engineering, Obafemi Awolowo University, Ile-Ife, Osun State, Nigeria. \\ *Author for Correspondence Email: jemails2000@yahoo.co.uk.
}

Article DOI: https://doi.org/10.37284/eaje.2.1.148

\begin{abstract}
Publication Date: ABSTRACT
26 Mar 2020 This research investigated the use of radioactive isotopes to study the Keywords: underground water characteristics of Ife South and Ife North Local governments area of Osun state in Southwestern Nigeria. The study aimed to determine the origin of water, the flow paths, residence time, and prediction of the geological formation of the study area. Twelve water samples were collected from the two local governments using standard methods for isotope study. Uranium ${ }^{234} \mathrm{U}$ and ${ }^{238} \mathrm{U}$ were analyzed for water samples using a gamma-ray spectrometer with Caesium Iodide (CsI) scintillation detector and physical analyses such as $\mathrm{pH}$, electrical conductivity, total dissolved solids, and temperature were also determined. The specific activity of ${ }^{238} \mathrm{U}$ ranged between $27.44 \pm 0.55$ to $36.89 \pm 1.70 \mathrm{~Bq} / \mathrm{kg}$; activity ratio of water samples from the two LGA ranged from 0.83 to 1.07 with average activity ratio of 0.901 . All the sample locations have an activity ratio of less than 1.00 except two locations in Ife South LGA (Ooni 1 and 2); a ${ }^{234} \mathrm{U}$ value of 30.386747 $\mathrm{Bq} / \mathrm{kg}$ was taken as constant. Ife North and Ife South have an average EC, turbidity, TDS, residence time of $493.3(\mu \mathrm{s} / \mathrm{cm})$, and $686.6(\mu \mathrm{s} / \mathrm{cm}) ; 1.2 \mathrm{NTU}$ and $3.33 \mathrm{NTU} ; 108.67 \mathrm{mg} / \mathrm{l}$ and $523.33 \mathrm{mg} / \mathrm{l} ; 2.889 \mathrm{ma}$ and $2.784 \mathrm{ma}$ respectively. In conclusion, the groundwater of the two LGA originate from the same source and are in the oxidation state; aquifers within Ife North and Ife South are separated with a barrier; hence its groundwater does not flow through one another. The residence time of groundwater in the two LGA is over $2.8 \mathrm{ma}$; Ooni 1 and 2 area is underlain by rocks rich in Uranium (granite), rocks underlying Ife South is younger to Ife North, Ife North is underlying by old weathered rocks (sedimentary rocks).
\end{abstract}

\section{APA CITATION}

Jeje, J., Arowolo, M., \& Sodipo, A. (2020). Application of Natural Radionuclide in the Subsurface Hydrogeology of Selected Two Local Governments in South Western Nigeria. East African Journal of Engineering, 2(1), 14-22. https://doi.org/10.37284/eaje.2.1.148 


\section{CHICAGO CITATION}

Jeje, Julius, Muritala Arowolo, and Adeniyi Sodipo. 2020. "Application of Natural Radionuclide in the Subsurface Hydrogeology of Selected Two Local Governments in South Western Nigeria". East African Journal of Engineering 2 (1), 1422. https://doi.org/10.37284/eaje.2.1.148.

\section{HARVARD CITATION}

Jeje, J., Arowolo, M. and Sodipo, A. (2020) "Application of Natural Radionuclide in the Subsurface Hydrogeology of Selected Two Local Governments in South Western Nigeria”, East African Journal of Engineering, 2(1), pp. 14-22. doi: 10.37284/eaje.2.1.148.

\section{IEEE CITATION}

J. Jeje, M. Arowolo, and A. Sodipo, "Application of Natural Radionuclide in the Subsurface Hydrogeology of Selected Two Local Governments in South Western Nigeria", EAJE, vol. 2, no. 1, pp. 14-22, Jun 2020.

\section{MLA CITATION}

Jeje, Julius, Muritala Arowolo, and Adeniyi Sodipo. "Application of Natural Radionuclide in the Subsurface Hydrogeology of Selected Two Local Governments in South Western Nigeria”. East African Journal of Engineering, Vol. 2, no. 1, Jun 2020, pp. 14-22, doi:10.37284/eaje.2.1.148.

\section{INTRODUCTION}

Water is a scarce commodity in many areas of the world. Due to the increases in population and expansion of agricultural and industrial enterprises, water needs are rapidly mounting, and many countries are now engaged in projects to develop water resources. In fact, the success of many current plans for economic development may well depend on the effective and judicious utilization of these resources. Hydrology has thus become a science of immense practical importance (Montoroi, Grünberger \& Nasri, 2002; Ma et al., 2009).

It was reported by Shiklomanov and Rodda (2004) that groundwater is the largest component of freshwater accessible for human use. While twothirds of the surface area of planet earth is covered with water, most of it is seawater or saline and only $2.5 \%$ is freshwater.

Isotope hydrology is a nuclear method that uses both stable and radioactive environmental isotopes to study the movements of water in the hydrological cycle. Isotopes can be used to study underground water sources to determine their source, how they are recharged, the risk of pollution, and whether they can be used in a sustainable manner (International Atomic Energy Agency, 2004).

The principles of groundwater dating by means of ${ }^{14} \mathrm{C}$ dated back to 40,000 years but were elaborated about fifty years ago; prior to this time, hydrologic estimates of the recharge rate and flow velocities of groundwater were poor (Geyh, 2003).
Radioisotopes function as tracers, which provide a convenient way of obtaining space-time integrals of motion of water molecules over both large and small range of space and time. It is now well recognized that a large number of cosmic rays produced isotopes are used for dating and tracing components geological/geophysical/geochemical systems (Geyh, 2003). Some of the tracers are well suited to study the time scales involved in the transport/mixing of water molecules since they follow the motion of water molecules. Others that do not follow the motion of the water molecules (as a result of their removal from the fluid by biogeochemical processes) serve as useful tracers to characterize properties of the reservoir. Isotopes are atoms of an element that are chemically identical but physically different. Both natural and artificial, stable, and radioactive nuclides are employed as tracers.

Naturally and artificially produced radionuclides have been extensively applied to study processes and time scales in hydrological cycles. The former is produced by (i) nuclear interactions of cosmic rays on the Earth, and (ii) radiogenic and nucleogenic processes associated with the ${ }^{238,234} U$ and ${ }^{232} \mathrm{Th}$. Artificially produced radionuclides are released from the testing of nuclear weapons and the operation of nuclear reactors. Each class of isotopic tracer has its own niche, providing detailed information on specific processes and time scales. For obtaining information about the hydrological cycle in its operation through different scales of space and time, it becomes necessary to 
simultaneously study two or more tracers. In fact, any model(s) used to treat tracer data has to be consistent with the information based on all the tracers. Thus, whilst it may not be apparent in some cases, multiple tracers are indeed often being deployed to study hydrological cycles (Lal, 2004; Shiklomanov et al., 2004)).

Tracer tests are significant and widely accepted methods to characterize the hydrogeological subsurface. Besides the detection of flow paths and structures, tracer tests are used to determine, among others, residence times, and transport parameters (Maduabuchi et al., 2006).

\section{MATERIALS AND METHODS}

\section{Description of Study Area}

The study areas were two local governments (IfeSouth and Ife-North) area of Osun state. Osun state is one of the southwestern states in Nigeria, located on latitude $7^{0} 30^{\prime} \mathrm{N}$ and longitude $4^{0} 30^{\prime} \mathrm{E}$; it covers an area of land approximately $14,875 \mathrm{~km}^{2}$ (Figure 1). Osun state falls within the tropical humid climate region where the wet and dry seasons are noticed prominently in the area. Osun state has a mean annual temperature of $26.2{ }^{\circ} \mathrm{C}$ and average annual precipitation of $1340 \mathrm{~mm}$.

Rahaman (1988) noted that the southwestern basement complex of Nigeria lies within the rest of the Precambrian rocks in Nigeria. He grouped the rocks in Osun state as migmatite-gneiss - quartzite complex comprising largely of sedimentary series with associated minor igneous rock intrusions which have been altered by metamorphic, migmatitic and granitic processes. Rahaman (1988) suggested that almost all the foliation exhibited by rocks of southwestern Nigeria, excluding the intrusive are tectonic in origin because pre-existing primary structures have been obliterated by subsequent deformation.

\section{Figure 1: Map showing sample locations}

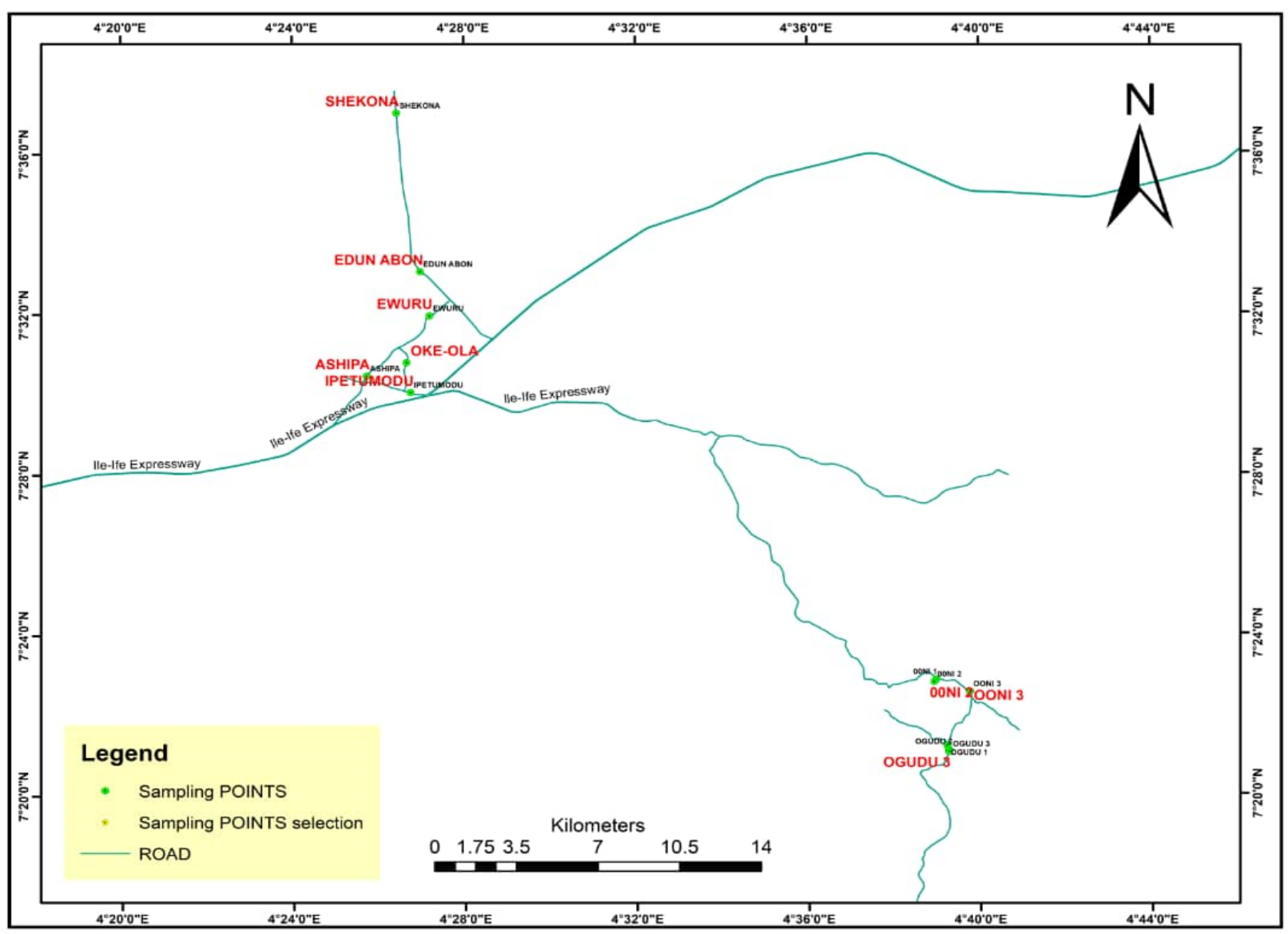




\section{Data Collection and Analysis}

Twelve (12) water samples were collected from underground wells in 12 locations within Ife-South and Ife-North local government areas (six water samples per LGA) of Osun state, which are over 3 $\mathrm{km}$ apart. Table 1 shows information about the locations where the samples were collected.

Each water sample was collected inside a $2.5 \mathrm{~L}$ plastic bottle and dosed with $25 \mathrm{ml}$ of $11 \mathrm{M}$ of HCL acid to prevent isotope. Prior to the dosage of each of the water samples collected, an in-situ $\mathrm{pH}$ test was carried out using a handheld $\mathrm{pH}$-meter. Electrical Conductivity test was carried out in the laboratory using DBK - Digital conductivity meter.

From each sample collected, $200 \mathrm{~g}$ were measured with an electrical sensitive weighing balance and firmly sealed in a cylindrical plastic container wrapped with masking tape for an incubation period of a minimum of 28 days so as to achieve radioactive secular equilibrium before being counted using the gamma-ray spectrometer. After the lapse of the incubation period, gamma-ray spectrometry was carried out by counting each sample for 10 hours using a well-calibrated Caesium Iodide (CsI) scintillation detector and processing the spectra using a Universal Radiation Spectrum Analyser.

\section{RESULTS AND DISCUSSION}

The electrical conductivity of the water samples collected in Ife-South was greater than those collected from Ife-North, as shown in Table 1. IfeNorth had an average EC of $493.3 \mu \mathrm{s} / \mathrm{cm}$ while Ife South has $686.6 \mu \mathrm{s} / \mathrm{cm}$. This is an indication that the geology of Ife-South has rock rich in metallic elements than the underlying Ife-North. The average temperature of the water samples collected in the two sample areas is $27.2{ }^{\circ} \mathrm{C}$; this only represents the temperature of the environment at the time the sample was collected; the aquifer is not a geothermal aquifer.

The maximum and minimum turbidity values of Ife-North and Ife-South are 2 and 1; 4 and 2, respectively. The average turbidity of Ife-North and Ife South is 1.2 NTU and 3.33 NTU, respectively. The difference in the turbidity of water in the two LGA suggests that water the rocks underlying IfeNorth has pore size smaller than that of Ife South that makes the water from Ife North less turbid. The turbidity of Ife south and Ife-North are within the tolerable limits of drinking water. Or it may flow from Ife South to Ife North because as water flows through the geological formation of Ife-South to Ife North, it becomes less turbid.

TDS values ranged between $520-2000 \mathrm{mg} / \mathrm{l}$ and 240-1180 mg/l, respectively; the average TDS for Ife North and Ife South is $108.67 \mathrm{mg} / \mathrm{l}$ and 523.33 $\mathrm{mg} / \mathrm{l}$. Since TDS indicates the level of solid that has been dissolved in water, the TDS value of water depends on the chemistry of the surrounding rock of the aquifer and rocks along its flow path. The long contact of the water with rocks in Ife North led to the dissolution of the rocks, which reflect in the high TDS values obtained from water samples from Ife North. The high value of TDS in Ife North is suggesting that the rocks in Ife North are more weathered than rocks in Ife South. The high TDS values are in agreement with a high residence time of waters in Ife North, which indicates that the waters have stayed longer in Ife North aquifer than the waters in Ife South. Also, the high residence time of waters in Ife North may suggest the rocks in Ife South are relatively younger than the rocks in Ife North.

Table 1: Physical characteristics of water samples in Ife-North Local Government Area

\begin{tabular}{|c|c|c|c|c|c|}
\hline $\begin{array}{l}\text { Location } \\
\text { Name }\end{array}$ & $\begin{array}{l}\text { Electrical } \\
(\mu \mathrm{s} / \mathrm{cm})\end{array}$ & Conductivity & $\begin{array}{l}\text { Turbidity } \\
\text { (NTU) }\end{array}$ & $\begin{array}{l}\text { TDS } \\
(\mathrm{mg} / \mathrm{l})\end{array}$ & $\begin{array}{l}\text { Temperature } \\
(0 \mathrm{C})\end{array}$ \\
\hline \multicolumn{6}{|c|}{ Ife-North } \\
\hline Ipetumodu & 370.00 & & 1.0 & 1440.00 & 27.2 \\
\hline Edun Abon & 460.00 & & 1.0 & 1000.00 & 27.2 \\
\hline Oke-Ola & 530.00 & & 1.0 & 620.00 & 27.1 \\
\hline Ewuru & 480.00 & & 1.0 & 520.00 & 27.2 \\
\hline Ashipa & 470.00 & & 1.0 & 940.00 & 27.3 \\
\hline
\end{tabular}


East African Journal of Engineering, Volume 2, Issue 1, 2020

Article DOI: https://doi.org/10.37284/eaje.2.1.148

\begin{tabular}{|c|c|c|c|c|c|}
\hline $\begin{array}{l}\text { Location } \\
\text { Name }\end{array}$ & $\begin{array}{l}\text { Electrical } \\
(\mu \mathrm{s} / \mathrm{cm})\end{array}$ & Conductivity & $\begin{array}{l}\text { Turbidity } \\
\text { (NTU) }\end{array}$ & $\begin{array}{l}\text { TDS } \\
(\mathrm{mg} / \mathrm{l})\end{array}$ & $\begin{array}{l}\text { Temperature } \\
(0 \mathrm{C})\end{array}$ \\
\hline Sekona & 650.00 & & 2.0 & 2000.00 & 27.0 \\
\hline Average & 493.33 & & 1.2 & 1086.67 & 27.2 \\
\hline \multicolumn{6}{|c|}{ Ife-South } \\
\hline Ooni 1 & 750.00 & & 2.0 & 360.00 & 27.2 \\
\hline Ooni 2 & 750.00 & & 2.0 & 320.00 & 27.2 \\
\hline Ooni 3 & 660.00 & & 4.0 & 240.00 & 27.3 \\
\hline Ogudu 1 & 610.00 & & 4.0 & 360.00 & 27.2 \\
\hline Ogudu 2 & 680.00 & & 4.0 & 1180.00 & 27.3 \\
\hline Ogudu 3 & 670.00 & & 4.0 & 680.00 & 27.1 \\
\hline Average & 686.67 & & 3.3 & 523.33 & 27.2 \\
\hline
\end{tabular}

The radioactive analysis was carried out on the water samples collected from Ife-North and IfeSouth to determine the quantity of uranium-234 and $238\left({ }^{234,238} \mathrm{U}\right)$ using a gamma-ray spectrometer with Caesium Iodide (CsI) scintillation detector. Uranium-234 was not detected in the water samples. Uranium has three naturally occurring isotopes, ${ }^{234} \mathrm{U}$ (half-life $2.45 \times 105$ years), ${ }^{235} \mathrm{U}$ (halflife $7.04 \times 108$ years), and ${ }^{238} \mathrm{U}$ (half-life $4.47 \times 109$ years). The relative atomic abundance of the three uranium isotopes has been reported by IUPAC to be U-234, 235, and 238 in natural Uranium to be $0.00548,0.7200$, and 99.2745 atom percent respectively. ${ }^{238} \mathrm{U}$ undergoes alpha decay to produce ${ }^{234} \mathrm{U}$, Figure 2 shows the decay series of radioactive elements, and this made it impossible to determined ${ }^{234} \mathrm{U}$ by the gamma-ray spectrometer using Caesium Iodide (CsI) scintillation detector which was used in the radioactive analysis. The non-destructive techniques such as gammaspectrometry (NaI and HPGe-detector) would have detected ${ }^{234} \mathrm{U}$, but it was unavailable. Although it is obvious that ${ }^{234} \mathrm{U}$ occurs in little percentage, yet it could still be detected by using some analytical techniques such as spiking with an element rich in ${ }^{234} \mathrm{U}$ (Rahaman 1988; International Atomic Energy Agency, 2004).).
Figure 2: Part of the ${ }^{238} U$ decay series (from ${ }^{238} U$ to ${ }^{222} \mathbf{R n}$ )

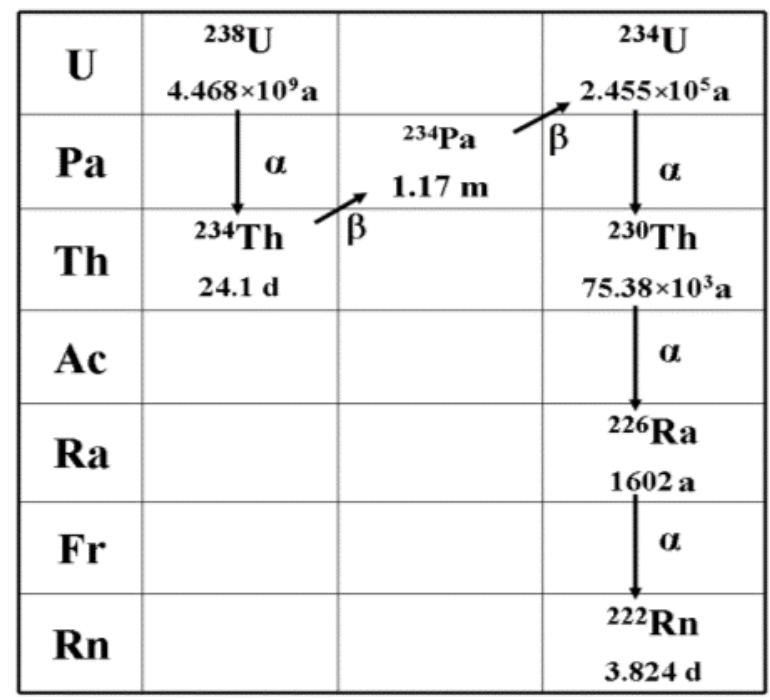

To determine the origin of water, flow path and residence time, uranium activity ratio $\left({ }^{234} \mathrm{U} /{ }^{238} \mathrm{U}\right)$ is needed, since ${ }^{234} \mathrm{U}$ could not be determined in the water samples, the average value of ${ }^{234} \mathrm{U}$ reported by Shiklomanov and Rodda (2004) was adopted because the water under study shows to be related with the sediment samples studied by Montoroi et al. (2002) because the values of ${ }^{238} U$ determined are within the same range. Table 2 showed the results of the isotopic analysis obtained on the water samples, while Table 3 shows the results of ${ }^{234} U /{ }^{238} U$ reported by Montoroi et al. (2002). The average ${ }^{238} \mathrm{U}$ determined by Montoroi et al. (2002) is $30.747 \mathrm{~Bq} / \mathrm{kg}$, while the average ${ }^{238} \mathrm{U}$ from this study is $33.97 \pm 0.95 \mathrm{~Bq} / \mathrm{kg}$, which is $9.48 \%$ different from one another. Hence, the average value of ${ }^{234} \mathrm{U}(30.386747 \mathrm{~Bq} / \mathrm{kg})$ from Montoroi et 
al., (2002) is assumed to be approximately same with what would have been obtained if it were determined by the equipment; thus, the value of

${ }^{234} \mathrm{U}$ is adopted as a constant in this study.

Table 2: Result of isotopic analysis

\begin{tabular}{lll}
\hline S/N & Sample & U-238(Bq/kg) \\
\hline $\mathbf{1}$ & & Ife-North \\
$\mathbf{2}$ & Ashipa & $34.14 \pm 0.42$ \\
$\mathbf{3}$ & Edun Abon & $36.44 \pm 1.57$ \\
$\mathbf{4}$ & Ewuru & $36.89 \pm 1.70$ \\
$\mathbf{5}$ & Ipetumodu & $33.44 \pm 0.72$ \\
$\mathbf{6}$ & Okeola & $36.25 \pm 1.51$ \\
\hline & Sekona & $33.70 \pm 0.51$ \\
\hline $\mathbf{7}$ & & \\
$\mathbf{8}$ & Ogudu 1 & $35.48 \pm 1.23$ \\
$\mathbf{9}$ & Ogudu 2 & $33.31 \pm 0.80$ \\
$\mathbf{1 0}$ & Ogudu 3 & $36.89 \pm 1.70$ \\
$\mathbf{1 1}$ & Ooni 1 & $29.36 \pm 0.14$ \\
$\mathbf{1 2}$ & Ooni 2 & $34.34 \pm 0.60$ \\
Total Average & Ooni 3 & $27.44 \pm 0.55$ \\
North Average & & $33.97 \pm 0.95$ \\
South Average & & $35.14 \pm 1.07$ \\
\hline
\end{tabular}

Note: U-234 was not detected in any of the water samples.

Table 3: U-234/U-238 activity ratio in sediment samples by alpha analysis

\begin{tabular}{|c|c|c|c|c|c|c|}
\hline \multirow[b]{2}{*}{ Sample name } & \multirow[b]{2}{*}{$\begin{array}{c}\text { U-234 } \\
(\mathrm{Bq} / \mathrm{kg})\end{array}$} & \multirow[b]{2}{*}{$\begin{array}{c}\text { U-238 } \\
\text { (Bq/kg) }\end{array}$} & \multicolumn{4}{|c|}{ U-234/U-238 Ratio } \\
\hline & & & $\begin{array}{c}\text { Reference } \\
\text { value }\end{array}$ & Measured & $\begin{array}{c}\% \\
\text { difference }\end{array}$ & $\begin{array}{l}\text { Measured/ } \\
\text { Reference }\end{array}$ \\
\hline Gurf hussin (middle) & 30.861 & 31.214 & 1 & 0.989 & 1.1 & 0.989 \\
\hline El madeq (middle) & 33.123 & 36.656 & 1 & 0.903 & 9.7 & 0.903 \\
\hline Wadi el arab (middle) & 28.346 & 30.034 & 1 & 0.944 & 5.6 & 0.944 \\
\hline Abo simble (middle) & 29.864 & 27.461 & 1 & 1.088 & -8.8 & 1.088 \\
\hline Abo simble (middle) & 31.231 & 31.687 & 1 & 0.986 & 1.4 & 0.986 \\
\hline Abo simble (middle) & 28.893 & 27.431 & 1 & 1.053 & -5.3 & 1.053 \\
\hline Average & 30.386 & 30.747 & & & & \\
\hline
\end{tabular}

It is obvious from table 8 that the range of specific activity of ${ }^{238} \mathrm{U}$ is $27.44 \pm 0.55-36.89 \pm 1.70 \mathrm{~Bq} / \mathrm{kg}$; activity ratio of water samples from the two LGA range from 0.83 to 1.07 with average activity ratio of 0.901 , all the sample locations have activity ratio less than one except two locations in Ife-South LGA which are Ooni 1 and 2. Figure 3 shows the graphical representation of activity ratios of various sample locations.

However, Ma (2009) reported that ${ }^{234} U$ and ${ }^{238} U$ are in radiological equilibrium if placed in a closed system, which is depicted by the activity ratio being equivalent to one. This suggests that the parent rocks or geology of the aquifers are relatively young volcanic ejecta, which initially had a ${ }^{234} \mathrm{U} /{ }^{238} \mathrm{U}$ activity ratio of 1.0 and has not been subjected too much leaching of ${ }^{234} U$ since its formation. Ooni 1 and 2 that has activity ratios greater than one, which might be because it is underlain by rocks rich in Uranium such granitic rocks. Although Ma et al. (2009) reported that groundwater mostly has activity ratio greater than unity, while weathered rocks have activity ratio less than unity, but the groundwater samples under study show otherwise, this could be because the 
underlying geology is not rich in Uranium. The aquifers are being recharged significantly by surface water; the geological formation of the aquifer is bounded by weathered rocks such as sedimentary rocks, including carbonate, clay, and phosphoric soil. The activity ratio of water samples from the two LGA is below unity, and within the same range; hence, it is suggesting that the aquifers in the two LGA are being recharged from the same source and have similar geological formation.
The activity ratio almost one is suggesting that the aquifer rock is relatively young, and groundwater from young rocks is considered to be in oxidizing state (oxic) while old rocks are known to be in reducing state (anoxic). Since it has been established that the groundwater is in the oxic state, the residence time of water is calculated using a mass-balance model (Ma et al., 2009).

\section{Figure 3: Graphical representation of activity ratio $\left({ }^{234} U /{ }^{238} U\right)$ per sample location}

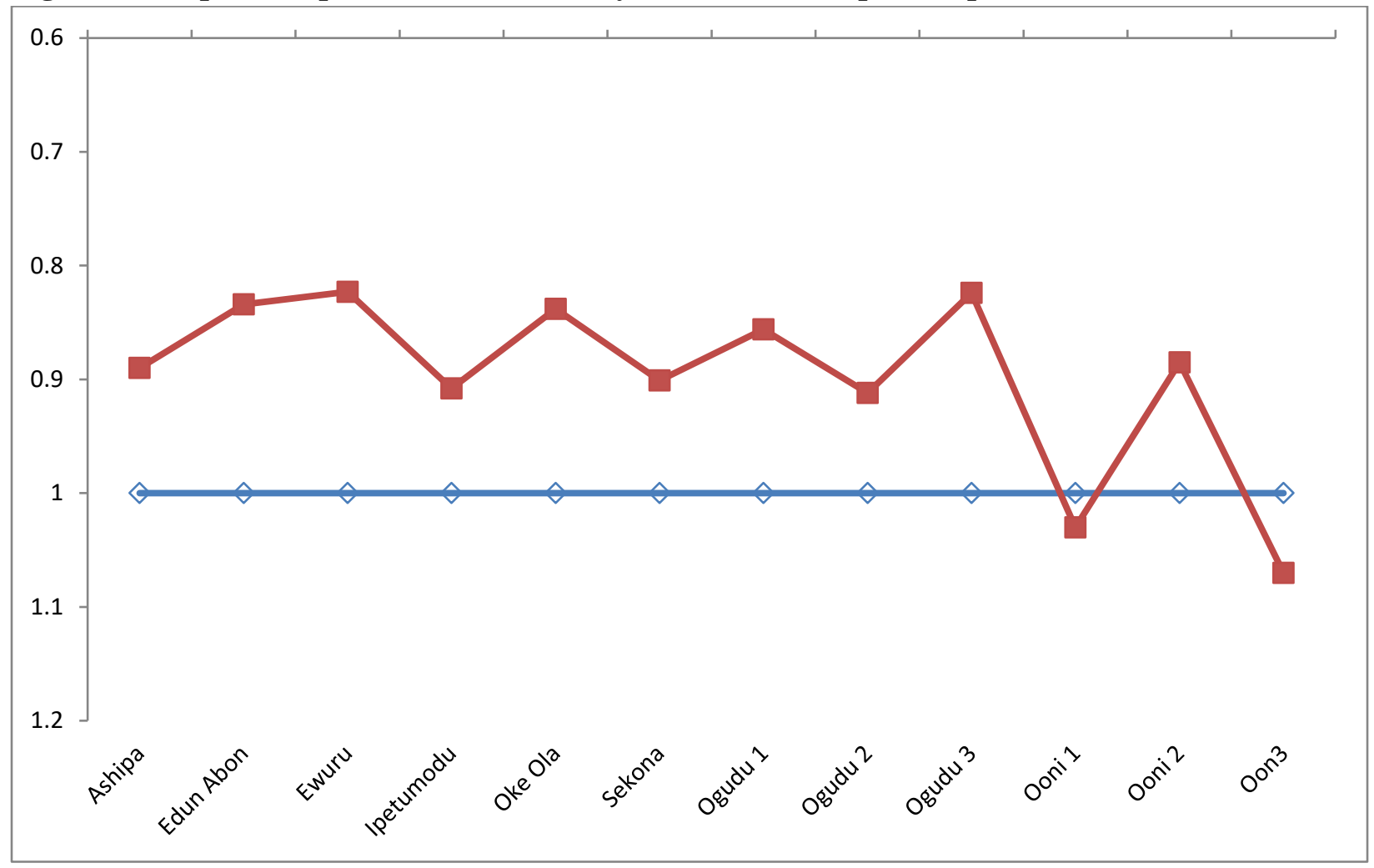

$\mathrm{t}_{1}=\ln \left(\mathrm{k}^{-1}\right)\left(\lambda_{4}\right)^{-1}, \mathrm{k}=1-\left[\left(\mathrm{C}_{8}{ }^{\mathrm{W}} \cdot \mathrm{R} \cdot\left(\mathrm{AR}_{\mathrm{t}}-1\right)\right]\left(\mathrm{M}_{\mathrm{s}}\right.\right.$. $\left.\mathrm{C}_{8}{ }^{\mathrm{R}} \cdot \mathrm{p}\right)^{-1}$

where $\lambda_{4}=2.8263 \times 10^{-6}\left(\mathrm{a}^{-1}\right) ; \mathrm{AR}_{\mathrm{t}}$ is activity ratio $\left({ }^{234} \mathrm{U} /{ }^{238} \mathrm{U}\right) ; \mathrm{C}_{8}{ }^{\mathrm{W}}=\mathrm{U}_{0}-{ }^{238} \mathrm{U}, \mathrm{C}_{8}{ }^{\mathrm{W}}$ is the measured concentration of ${ }^{238} \mathrm{U}$ in solution at the point of sampling; $\mathrm{M}_{\mathrm{s}}$ is solid mass to fluid unit volume ratio; $\mathrm{R}$ is the retardation factor; $\mathrm{C}_{8} \mathrm{~W}$ is the concentration of ${ }^{238} \mathrm{U}$ in solid phase and " $\mathrm{p}$ " is the recoil lose factor. Where $\mathrm{U}_{0}=2.6 ; \mathrm{M}_{\mathrm{s}}=9.2 ; \mathrm{R}=24$ and $\mathrm{p}=3.6 \times 10^{-6}\left(\mathrm{a}^{-1}\right)(\mathrm{Lal}, 2015)$.
The residence time of water range from 2.4503.206 ma, Ife-North LGA, and Ife-South LGA has an average residence time of 2.889 ma and 2.784 ma, respectively. This simply implies that the water in Ife-North LGA has stayed longer within the rocks of the aquifer than that of Ife-South LGA, this may mean the rocks in Ife-North LGA are relatively older than rocks in Ife-South LGA, or the permeability of rocks in Ife-North LGA is lower to those of the rock types in Ife-South LGA. 
East African Journal of Engineering, Volume 2, Issue 1, 2020

Article DOI: https://doi.org/10.37284/eaje.2.1.148

Table 4: Activity ratio of sample locations

\begin{tabular}{|c|c|c|c|c|c|c|c|}
\hline Sample & $\begin{array}{c}{ }^{238} \mathrm{U} \\
(\mathrm{Bq} / \mathrm{kg})\end{array}$ & $\begin{array}{c}{ }^{234} \mathbf{U} \\
(\mathrm{Bq} / \mathrm{kg})\end{array}$ & $\begin{array}{c}\text { Activity ratio } \\
{ }^{234} U /{ }^{238} U\end{array}$ & $\begin{array}{c}{ }^{238} \mathrm{U} \\
(\mathbf{p p m})\end{array}$ & $\begin{array}{c}\mathrm{C}_{8}{ }^{\mathrm{W}}= \\
\mathbf{U}_{0}- \\
238 \mathrm{U}\end{array}$ & $\begin{array}{l}\mathrm{C}_{8}^{\mathrm{R}}= \\
\mathbf{U}_{0}+ \\
{ }_{238} \mathbf{U}\end{array}$ & $\begin{array}{l}\text { Residence } \\
\text { time (ma) }\end{array}$ \\
\hline \multicolumn{8}{|c|}{ Ife-North } \\
\hline Ashipa & $34.14 \pm 0.42$ & 30.386 & 0.89 & 2.753 & -0.153 & 5.353 & 2.735 \\
\hline $\begin{array}{l}\text { Edun } \\
\text { Abon }\end{array}$ & $36.44 \pm 1.57$ & 30.386 & 0.834 & 2.938 & -0.338 & 5.538 & 3.149 \\
\hline Ewuru & $36.89 \pm 1.70$ & 30.386 & 0.823 & 2.975 & -0.375 & 5.575 & 3.206 \\
\hline Ipetumodu & $33.44 \pm 0.72$ & 30.386 & 0.908 & 2.696 & -0.096 & 5.296 & 2.511 \\
\hline Okeola & $36.25 \pm 1.51$ & 30.386 & 0.838 & 2.923 & -0.323 & 5.523 & 3.125 \\
\hline Sekona & $33.70 \pm 0.51$ & 30.386 & 0.901 & 2.717 & -0.117 & 5.317 & 2.605 \\
\hline \multicolumn{8}{|c|}{ Ife-South } \\
\hline Ogudu 1 & $35.48 \pm 1.23$ & 30.386 & 0.856 & 2.861 & -0.261 & 5.461 & 3.012 \\
\hline Ogudu 2 & $33.31 \pm 0.80$ & 30.386 & 0.912 & 2.686 & -0.086 & 5.286 & 2.456 \\
\hline Ogudu 3 & $36.89 \pm 1.70$ & 30.386 & 0.824 & 2.975 & -0.375 & 5.575 & 3.204 \\
\hline Ooni 1 & $29.36 \pm 0.14$ & 30.386 & 1.03 & 2.367 & 0.233 & 4.967 & 2.45 \\
\hline Ooni 2 & $34.34 \pm 0.60$ & 30.386 & 0.885 & 2.769 & -0.169 & 5.369 & 2.785 \\
\hline Ooni 3 & $27.44 \pm 0.55$ & 30.386 & 1.107 & 2.212 & 0.388 & 4.812 & 2.798 \\
\hline Mean & & & 0.901 & & & & \\
\hline
\end{tabular}

\section{CONCLUSION}

The study showed that the subsurface water of Ife North and Ife South originate or are being recharged from the same source, the water in the two LGA does not flow through one another which may be because the water table is at the same elevation or presence of impervious boundary rocks between Ife North and Ife South. Water in Ife North has a higher residence time than that of Ife South. It is apparent that the water in the geological formation of Ife North has stayed longer than that of Ife South. The rocks in Ife-South are rich in metallic elements than that of Ife North; rocks in Ife North are old weathered rocks. Despite the proximity and small size of the two study areas, the areas are composed of different age of rocks which were formed over $1 \mathrm{~m}$ apart.

\section{REFERENCES}

Geyh M. A. (2003). Radiocarbon dating of old groundwater - history, limits, and future. International Symposium on Isotope Hydrology and Integrated Water Resources Management (pp. 23-24). Vienna: International Atomic Energy Agency.

International Atomic Energy Agency. (2004). Managing water resources using isotope hydrology. International Atomic Energy Agency. Retrieved from https://www.iaea.org/sites/default/files/water.p df

Lal, D. (2004). Hydrological process studies using cosmic-ray produced radionuclides. Isotope Hydrology and Integrated Water Resources Management, 13.

Ma, J., Ding, Z., Edmunds, W. M., Gates, J. B., \& Huang, T. (2009). Limits to recharge of groundwater from Tibetan plateau to the Gobi Desert, implications for water management in the mountain front. Journal of Hydrology, 364(1-2), 128-141. 
Maduabuchi, C., Faye, S., \& Maloszewski, P. (2006). Isotope evidence of palaeorecharge and palaeoclimate in the deep confined aquifers of the Chad Basin, NE Nigeria. Science of the total environment, 370(2-3), 467-479.

Montoroi, J. P., Grünberger, O., \& Nasri, S. (2002). Groundwater geochemistry of a small reservoir catchment in Central Tunisia. Applied Geochemistry, 17(8), 1047-1060.

Rahaman M. (1988). Recent advances in the study of the Basement Complex of Nigeria. In Precambrian Geology of Nigeria, 11-43.

Shiklomanov, I. A., \& Rodda, J. C. (Eds.). (2004). World water resources at the beginning of the twenty-first century. Paris: Cambridge University Press. 